\title{
Penggunaan Informasi Finansial dan Kinerja Nonfinansial dalam Pengalokasian Anggaran Dekonsentrasi dan Tugas Pembantuan
}

\author{
Arif Sujoko ${ }^{1^{*}}$, Nurkholis ${ }^{1}$, Erwin Saraswati ${ }^{1}$ \\ ${ }^{1}$ Fakultas Ekonomi dan Bisnis Universitas Brawijaya \\ *Penulis korespondensi; E-mail: arifsujoko@yahoo.com
}

\begin{abstract}
ABSTRAK
Penelitian ini bertujuan untuk memberikan bukti empiris penggunaan informasi finansial dan kinerja nonfinansial dalam pembuatan keputusan alokasi anggaran dekonsentrasi dan tugas pembantuan. Penggunaan kedua jenis informasi ini diindikasikan adanya pengaruh positif informasi tersebut terhadap alokasi anggaran. Sampel penelitian diperoleh dengan pusposive sampling terhadap dinas kelautan dan perikanan provinsi sebagai satuan kerja dekonsentrasi dan tugas pembantuan dari Direktorat Jenderal Perikanan Budidaya. Hasil analisis regresi linier berganda dengan metode Ordinary Least Square (OLS) menunjukkan bahwa informasi finansial dan kinerja nonfinansial masingmasing memiliki pengaruh positif terhadap alokasi anggaran. Hal ini menunjukkan bahwa informasi finansial dan kinerja nonfinansial digunakan dalam pembuatan keputusan alokasi anggaran dekonsentrasi dan tugas pembantuan.
\end{abstract}

Kata kunci: Informasi finansial, informasi kinerja nonfinansial, alokasi anggaran.

\begin{abstract}
This research aims to give empirical evidence about usefulness of financial and nonfinancial performance information in deconcentration and co-administration budget allocation decision. The usefulness of these informations is indicated by the positive influence between these information and budget allocation. The samples of the research are drawn by using purposive sampling from provincial marine and fisheries services as deconcentration and co-administration unit from Directorate General of Aquaculture. The results of multiple regression analysis using ordinary least square (OLS) method shown that financial information had positive influence on budget allocation and so did nonfinancial performance information. These results given evidence that financial and nonfinancial performance information were useful in deconcentration and co-administration budget allocation decision.
\end{abstract}

Keywords: Financial information, nonfinancial performance information, budget allocation.

\section{PENDAHULUAN}

Keputusan alokasi anggaran secara teknis merupakan suatu proses yang kompleks (Willoughby 2002). Proses ini selalu dihadapkan pada masalah utama, yaitu penentuan faktor yang menjadi dasar dalam pengalokasian sumber daya yang terbatas dengan tujuan untuk memaksimalkan utilitas sosial (Key 1940). Pada tingkat manajerial, pembuatan keputusan alokasi anggaran cenderung menggunakan pendekatan technical rasional terkait tujuan dari kegiatan operasional pemerintah (Gibran dan Sekwat 2009). Pendekatan ini membutuhkan ketersediaan informasi, baik untuk penilaian kinerja, maupun untuk membuat keputusan alokasi anggaran (Forrester 2002).
Informasi yang digunakan untuk membuat keputusan alokasi anggaran terdiri dari informasi finansial dan kinerja nonfinansial.

Penggunaan informasi finansial dalam pembuatan keputusan alokasi anggaran telah dikonfirmasi oleh Reck (2001) dan Dorta-Velazques et al. (2010). Survai oleh Daniels dan Daniels (1991), de Sousa et al. (2012), serta Susanto dan Djuminah (2015) menunjukkan bahwa informasi finansial digunakan dalam pembuatan keputusan alokasi anggaran. Sebaliknya, Susilo dan Akbar (2015) mengindikasikan bahwa informasi finansial tidak digunakan dalam membuat keputusan alokasi anggaran. Ketidakkonsistenan hasil ini juga didapatkan dalam penelitian penggunaan informasi kinerja nonfinansial dalam pembuatan keputusan 
alokasi anggaran. Reed (1986), Grizzle (1987), Gilmour dan Lewis (2006) membuktikan bahwa informasi kinerja nonfinansial digunakan dalam membuat keputusan alokasi anggaran, namun Connely dan Tompkins (1989), Rivenbark dan Kelly (2000), serta Reck (2001) menunjukkan bukti yang berlawanan, informasi kinerja nonfinansial tidak digunakan dalam membuat keputusan alokasi anggaran.

Berdasarkan hasil penelitian yang tidak konsisten tersebut, peneliti melakukan studi empiris tentang penggunaan informasi finansial dan kinerja nonfinansial dalam pembuatan keputusan alokasi anggaran. Penelitian ini mengacu pada Reck (2001) yang, sepengetahuan peneliti, belum pernah dilakukan di Indonesia. Berbeda dengan Reck (2001) yang melakukan analisis terhadap data primer, penelitian ini menggunakan analisis data sekunder. Dalam hal obyek, penelitian ini tidak menggunakan obyek pemerintahan kabupaten/ kota, tetapi obyek penelitiannya adalah penganggaran dekonsentrasi dan tugas pembantuan di Direktorat Jenderal Perikanan Budidaya (DJPB) Kementerian Kelautan dan Perikanan (KKP).

Pemilihan obyek penelitian di DJPB didasarkan pada pertimbangan bahwa DJPB merupakan instansi yang memiliki tanggung jawab besar dalam pencapaian sasaran pembangunan nasional, khususnya pencapaian target produksi ikan dalam Rencana Pembangunan Jangka Menengah Nasional (RPJMN) 2015-2019 sebesar 40-50 juta ton pada tahun 2019 (Kementerian PPN/ Bappenas 2014). Pemilihan obyek penelitian di DJPB juga didasarkan pada indikasi efektivitas manajemen kinerja yang ditunjukkan dengan relatif tingginya rata-rata pertumbuhan volume produksi perikanan budidaya dibandingkan pertumbuhan alokasi anggaran untuk DJPB dalam 8 tahun terakhir. Selain hal itu, pemilihan obyek penelitian di DJPB juga didasarkan pada pertimbangan kualitas informasi finansial. Sebagai bagian dari Laporan Keuangan KKP yang dalam periode 2009 - 2014 mendapat opini wajar tanpa pengecualian (WTP) dengan paragraf penjelas (BPK 2015), Laporan Keuangan Satker Dekonsentrasi dan Tugas Pembantuan di lingkungan DJPB diasumsikan memiliki kandungan informasi finansial yang cukup berkualitas untuk membuat keputusan. Laporan keuangan yang mendapat opini WTP merupakan bahan yang tepat dan bisa dipercaya untuk mengambil keputusan perencanaan anggaran (Azis 2015).

Penelitian ini bertujuan untuk memberikan bukti empiris penggunaan informasi finansial dalam pembuatan keputusan alokasi anggaran dekonsentrasi dan tugas pembantuan serta memberikan bukti empiris penggunaan informasi kinerja nonfinansial dalam pembuatan keputusan alokasi anggaran dekonsentrasi dan tugas pembantuan. Informasi finansial dan kinerja nonfinansial dikatakan berguna apabila terdapat pengaruh positif informasi tersebut terhadap keputusan alokasi anggaran dekonsentrasi dan tugas pembantuan.

\section{Teori Keagenan (Agency Theory)}

Teori keagenan menjelaskan hubungan keagenan, yaitu suatu kontrak penugasan dari principal kepada agen untuk melakukan beberapa pekerjaan yang sesuai kepentingan principal melalui pendelegasian sebagian otoritas pembuatan keputusan kepada agen (Jensen dan Meckling 1976). Dalam hubungan keagenan muncul situasi informasi yang asimetris (information asymmetries) antara principal dan agen yang dapat mengakibatkan dua masalah keagenan, yaitu adverse selection dan moral hazard (Eisenhardt 1989, Shapiro 2005). Agency Theory didasarkan pada asumsi bahwa masing-masing pihak adalah utility maximizer sehingga agen tidak selalu bertindak yang terbaik sesuai dengan keinginan principal. Untuk mengurangi ketidaksesuaian tindakan agen dengan keinginan principal tersebut, principal perlu mendesain kontrak yang paling optimal dengan cara membangun skema reward (Eisenhardt 1985).

Dalam perspektif pendelegasian tugas di pemerintahan yang mengikuti pola hierarki, suatu pendelegasian tugas termasuk dalam hubungan keagenan apabila memenuhi tiga syarat: (1) pekerjaan dari pemerintah didelegasikan kepada unit kerja yang lebih rendah, (2) pemerintah mengalokasikan sumberdaya untuk melaksanakan pekerjaan tersebut, dan (3) pemerintah berkepentingan dengan capaian kinerja atas pekerjaan yang ditugaskan tersebut (Kivisto 2007).

\section{Pengukuran Kinerja dan Penganggaran}

Principal memerlukan pengukuran kinerja untuk mengevaluasi kinerja agen, tetapi pengukuran kinerja seringkali tidak dapat memberikan gambaran yang sebenarnya dari tindakan agen. Risiko pengukuran kinerja akan relatif besar, apabila hanya menggunakan ukuran kinerja tunggal. Risiko ini dapat dikurangi dengan menggunakan beragam ukuran kinerja, baik ukuran finansial maupun nonfinansial (Feltham dan Xie 1994).

Pengukuran kinerja berkaitan dengan akuntabilitas. Esensi dari akuntabilitas adalah pemberian informasi dari satu pihak (agen) kepada pihak lain (principal) sebagai bentuk pertanggungjawaban atas perilaku agen beserta konse- 
kuensi dari perilaku tersebut (Ijiri 1983). Informasi yang disampaikan bisa digunakan sebagai dasar pemberian sanksi (Biela dan Papadopoulus 2010) dan reward kepada agen (Baiman 1990, Melkers dan Willoughby 2005). Pemberian sanksi kepada agen yang berkinerja rendah melalui tindakan pemecatan terkadang sulit dilakukan oleh organisasi pemerintah. Apabila muncul kesulitan untuk memberhentikan agen, maka tindakan lain yang dapat dilakukan oleh principal adalah merubah alokasi anggaran (Weissman 1983 dalam Reck 2001).

Penggunaan anggaran sebagai reward dalam hubungan keagenan di sektor pemerintahan tidak dapat dilepaskan dari pentingnya anggaran bagi birokrasi. Peningkatan jumlah anggaran dapat digunakan untuk mewujudkan banyak tujuan, seperti tambahan honor, reputasi publik, kekuasaan, dan peningkatan output dari instansi (Mueller 1979 dalam Berg 1984). Pemberian reward anggaran bagi unit kerja yang berkinerja baik dikenal juga metode alokasi anggaran berbasis merit (Layzell 1998).

\section{Informasi Finansial dan Kinerja Nonfinan- sial}

Tujuan utama dari laporan keuangan adalah untuk menyediakan informasi kepada pengguna (Beaver dan Demski 1974). Informasi finansial adalah informasi atau data dalam laporan keuangan yang memiliki efek material secara signifikan terhadap keputusan pengeluaran, penganggaran, atau keputusan finansial lainnya atau yang digunakan untuk menentukan kepatuhan pada hukum dan peraturan (Aman 2012).

Penggunaan informasi finansial untuk pengambilan keputusan dikenal dengan konsep decision usefulness. Konsep ini berintikan pada tujuan dari akuntansi, yaitu untuk menyediakan informasi finansial yang digunakan dalam pembuatan keputusan (Staubus 2000 dalam Tollerson 2012). Suatu informasi memenuhi kriteria decision usefulness, apabila informasi tersebut digunakan untuk membuat keputusan tertentu, misalnya keputusan pengalokasian sumber daya yang terbatas (Deegan 2010).

Pendekatan decision usefulness dipakai secara luas oleh banyak standard setter dalam menyusun standar akuntansi (Scott 2009). Dewan Standar Akuntansi Pemerintahan (DSAP), sebagai standard setter SAP, juga menggunakan pendekatan decision usefulness sebagaimana tampak dalam Kerangka Konseptual Akuntansi Pemerintahan (PP 71/ 2010).

Untuk kepentingan pembuatan keputusan, cukup banyak data dalam laporan keuangan yang berpotensi memiliki kandungan informasi karena dinilai relevan dalam pembuatan keputusan. Oleh karena itu, perlu dilakukan identifikasi atas data dalam laporan keuangan yang dianggap paling penting oleh penggunanya, khususnya manajemen pemerintah. Selain itu, penentuan informasi yang relevan tersebut perlu mempertimbangkan kesesuaian informasi dengan kebutuhan principal (Reck 1996). Principal akan menganggap penting suatu informasi dalam laporan keuangan agen, apabila informasi tersebut juga menggambarkan kinerja principal atau bersesuaian dengan tujuan principal.

Jorge et al. (2008), Nogueira et al. (2013), serta Susanto dan Djuminah (2015) menemukan bahwa laporan keuangan yang dianggap paling bermanfaat bagi manajemen pemerintah dalam membuat keputusan adalah laporan anggaran berbasis kas. Adanya persepsi bahwa laporan anggaran berbasis kas relatif lebih penting daripada laporan keuangan akrual tidak dapat dilepaskan dari kultur birokrasi yang telah menggunakannya dalam waktu relatif lama sehingga relatif dapat dipahami dan dimengerti dengan baik (Liguori et al. 2012).

Dalam laporan anggaran berbasis kas, informasi realisasi belanja merupakan informasi yang paling sering diperhatikan oleh manajemen pemerintah (Jorge et al. 2008). Unit kerja yang tidak mampu merealisasikan keseluruhan anggaran belanja yang sudah dialokasikan akan dianggap sebagai unit kerja yang tidak membutuhkan keseluruhan dana yang diminta sehingga alokasi anggaran pada masa depan akan dikurangi (Reck 2001). Pengalaman praktis dari Pemerintah Singapura, realisasi belanja digunakan dalam mempertimbangkan pengalokasian anggaran. Kementerian dengan realisasi belanja kurang dari $95 \%$ dari yang dianggarkan akan mendapatkan penyesuaian berupa pengurangan anggaran pada periode selanjutnya (Blondal 2006).

Dalam hal kesesuaian informasi finansial dengan kebutuhan principal, sebagai bagian dari organisasi pemerintahan, kinerja finansial manajemen unit kerja tidak dapat dilepaskan dari kepentingan makro pemerintah untuk menjaga realisasi belanja pada tingkat yang tinggi sehingga dapat mencapai tujuan pembangunan ekonomi. Djojohadikusumo (1994) menyatakan bahwa salah satu ciri pokok dalam proses pembangunan ekonomi adalah pertumbuhan ekonomi/ pendapatan nasional. Secara fungsional, perhitungan pendapatan nasional dengan menggunakan metode pengeluaran melibatkan variabel government expenditure. Oleh karena itu, tingginya tingkat realisasi belanja pemerintah akan berkontribusi positif terhadap pertumbuhan ekonomi. Pengaruh 
belanja pemerintah terhadap tingkat pertumbuhan pendapatan nasional dinyatakan oleh Lindauer dan Velenchick (1992), serta Loizides dan Vamvoukas (2005).

Walaupun informasi realisasi anggaran dalam laporan realisasi anggaran (LRA) penting bagi pemerintah,. kehadiran LRA masih belum mampu menggambarkan hal yang seharusnya dicapai oleh pemerintah, sehingga dibutuhkan informasi lain yang dapat menunjukkan kinerja pemerintah (Ives 1987). Dalam hal ini, Reck (1996) berpendapat bahwa informasi kinerja nonfinansial penting bagi pengguna laporan keuangan pemerintah. Fokus dari informasi kinerja nonfinansial ini adalah output dan outcome yang berhasil dicapai oleh agen (Reed 1984, Stiefel et al. 1999, Reck 2001).

\section{Dekonsentrasi dan Tugas Pembantuan}

Salah satu bentuk desentralisasi fiskal adalah dekonsentrasi, yaitu pelepasan tanggung jawab yang sebelumnya berada di tangan pemerintah pusat kepada instansi vertikal di daerah atau kepada pemerintah daerah (Bird dan Vaillancourt 2000). Sementara itu, Boex (2011) menyatakan bahwa dekonsentrasi merupakan entitas administrasi lokal yang menjadi bagian dari hierarki administrasi pemerintah pusat, termasuk jurisdiksi anggarannya.

Dalam konteks Indonesia, pelaksanaan urusan pemerintahan di daerah diselenggarakan dengan asas desentralisasi, dekonsentrasi, dan tugas pembantuan. Desentralisasi digunakan untuk melaksanakan secara otonom urusan pemerintahan yang sudah menjadi urusan daerah, sedangkan dekonsentrasi dan tugas pembantuan digunakan untuk menyelenggarakan urusan pemerintah pusat di daerah, baik yang dilimpahkan melalui dekonsentrasi, maupun yang ditugaskan melalui tugas pembantuan (UU 23/ 2014). Pelaksanaan dekonsentrasi dan tugas pembantuan secara umum adalah hal yang sama, dimana pemerintah pusat terlibat dalam pengelolaan anggarannya (Sidik 2002).

\section{Pengembangan Hipotesis}

Hubungan antara pemerintah pusat dan pemerintah daerah dalam pelaksanaan dekonsentrasi dan tugas pembantuan sebagaimana dimaksud UU 23/ 2014 pada hakikatnya merupakan bentuk hubungan keagenan. Dalam konteks desentralisasi, Ranis (2012) berpendapat bahwa pemerintah pusat bertindak sebagai principal, sedangkan pemerintah daerah sebagai agen.

Agen tidak selalu bertindak sesuai dengan keinginan principal, sehingga principal perlu mengendalikan tindakan agen agar sesuai dengan keinginannya, sebagai misal dengan memberikan reward (Eisenhardt 1985). Sanksi dan reward dalam hubungan keagenan di sektor pemerintahan diwujudkan dalam bentuk perubahan alokasi anggaran (Weisman 1983 dalam Reck 2001). Dalam hal ini, principal akan memberikan reward berupa alokasi anggaran yang relatif banyak kepada agen yang bertindak sesuai dengan keinginan principal.

Oleh karena tindakan agen tidak dapat diamati secara langsung, principal membutuhkan suatu informasi outcome sebagai dasar pemberian reward (Eisendhardt 1985). Informasi ini akan menjadi input bagi pembuat keputusan yang selanjutnya diolah untuk menghasilkan output berupa keputusan (Libby dan Lewis 1977). Informasi outcome dari agen yang relatif baik dapat meningkatkan kepuasan principal, sehingga agen akan mendapat reward alokasi anggaran yang relatif banyak.

Pemerintah memang tidak memiliki outcome finansial dalam bentuk profit (Reck 1996), tetapi hal ini bukan berarti bahwa pemerintah tidak memiliki informasi finansial sebagai dasar pembuatan keputusan. Laporan keuangan pemerintah sebagai sumber informasi finansial disusun dengan menggunakan pendekatan decision usefulness (Ijiri 1983, PP 71/ 2010). Penggunaan informasi finansial dalam pembuatan keputusan alokasi anggaran telah dikonfirmasi Reck (2001) dan Dorta-Velazques et al. (2010). Petunjuk penggunaan informasi finanisal dalam pembuatan keputusan alokasi anggaran juga diindikasikan oleh Daniels dan Daniels (1991), de Sousa et al. (2012), serta Susanto dan Djuminah (2015).

Oleh karena hal tersebut di atas, peneliti mengembangkan hipotesis sebagai berikut:

$\mathrm{H}_{1}$ : Informasi finansial berpengaruh positif terhadap keputusan alokasi anggaran dekonsentrasi dan tugas pembantuan

Penggunaan informasi finansial sebagai ukuran kinerja tunggal tidak mampu memberikan gambaran terbaik atas kinerja agen. Untuk memperbaiki hal ini, Feltham dan Xie (1994) menyarankan agar principal menggunakan ukuran kinerja yang beragam, baik ukuran finansial, maupun nonfinansial. Penambahan ukuran kinerja nonfinansial akan mampu menunjukkan kinerja yang seharusnya dicapai oleh pemerintah (Ives 1987).

Informasi kinerja nonfinansial dapat berupa outcome yang merupakan alat ukur keberhasilan atau kegagalan suatu program (Reed 1984). Agen yang memiliki kinerja outcome yang tinggi akan mendapat reward anggaran yang lebih besar 
(Robinson dan Brumby 2005). Dalam skema penganggaran kinerja yang menjadikan anggaran sebagai reward, informasi kinerja nonfinansial akan dikumpulkan terlebih dahulu dan alokasi akan dibuat berdasarkan informasi kinerja tersebut (Ewell 1999).

Grizzle (1987) menunjukkan adanya indikasi penggunaan informasi kinerja nonfinansial dalam pembuatan keputusan alokasi anggaran, sedangkan pengaruh informasi kinerja nonfinansial dalam pembutan keputusan alokasi anggaran telah dikonfirmasi oleh Reed (1986) serta Gilmour dan Lewis (2006). Dengan berdasar pada hal tersebut di atas, peneliti mengembangkan hipotesis sebagai berikut:

$\mathrm{H}_{2}$ : Informasi kinerja nonfinansial berpengaruh positif terhadap keputusan alokasi anggaran dekonsentrasi dan tugas pembantuan

\section{METODE PENELITIAN}

\section{Sumber Data}

Penelitian ini menggunakan data sekunder yang diperoleh dari unit kerja di lingkungan kantor pusat DJPB. Data finansial yang terdiri dari alokasi dan realisasi belanja anggaran dekonsentrasi dan tugas pembantuan diperoleh dari Sekretariat DJPB, sedangkan data kinerja nonfinansial berupa realisasi produksi perikanan budidaya diperoleh dari Direktorat Produksi dan Usaha Perikanan Budidaya.

\section{Populasi dan Sampel}

Penelitian ini menggunakan unit analisis dinas kelautan dan perikanan provinsi yang ditetapkan sebagai satuan kerja pelaksana dekonsentrasi dan tugas pembantuan oleh DJPB pada tahun 2014 - 2017. Selanjutnya sampel dipilih dengan metode purposive dengan kriteria memiliki informasi finansial dan kinerja nonfinansial pada saat pembuatan keputusan alokasi anggaran. Berdasarkan kriteria tersebut, populasi penelitian ini terdiri dari 135 unit analisis yang 133 diantaranya dijadikan sampel penelitian.

\section{Definisi Operasional Variabel Penelitian}

Penelitian ini menggunakan tiga variabel penelitian yang terdiri dari satu variabel dependen dan dua variabel independen. Variabel dependen yang digunakan adalah alokasi anggaran, sedangkan variabel independen yang digunakan adalah informasi finansial dan informasi kinerja nonfinansial. Definisi operasional ketiga variabel penelitian dapat dijelaskan sebagai berikut:
1. Alokasi anggaran

Alokasi anggaran adalah jumlah rupiah anggaran yang dialokasikan kepada satker dekonsentrasi dan tugas pembantuan dinas kelautan dan perikanan provinsi. Penetapan alokasi secara legal dilakukan dalam bentuk Daftar Isian Pelaksanaan Anggaran (DIPA). Untuk alokasi anggaran tahun 2017, pada saat penelitian dilakukan DIPA belum ditetapkan, sehingga digunakan data alokasi yang dipublikasikan dalam Rapat Teknis Perencanaan.

2. Informasi finansial

Informasi finansial adalah informasi tingkat realisasi anggaran belanja. Realisasi anggaran belanja diperoleh dari perbandingan total realisasi anggaran belanja dengan total pagu anggaran yang dinyatakan dalam persen. Informasi realisasi anggaran dalam persen ini disajikan secara langsung dalam LRA yang dihasilkan oleh Sistem Akuntansi Instansi Berbasis Akrual (SAIBA).

3. Informasi kinerja nonfinansial

Informasi kinerja nonfinansial adalah informasi kinerja outcome dari program tunggal DJPB berupa volume produksi perikanan budidaya dalam satuan ton. Data ini diperoleh dari Buku Statistik Perikanan Budidaya Indonesia yang diterbitkan oleh Direktorat Produksi dan Usaha DJPB sebagai kompilasi atas data statistik tingkat provinsi, kecuali tahun 2015 data yang tersedia masih berupa dokumen hasil validasi tingkat nasional. Dalam hal ini, statistik perikanan budidaya dihasilkan dari survai yang melibatkan DJPB, dinas kelautan dan perikanan provinsi, serta dinas kelautan dan perikanan kabupaten/ kota.

\section{Model Penelitian}

Model penelitian yang digunakan dalam penelitian ini adalah model regresi berganda sebagai berikut:

$\mathbf{Y}_{\text {it }}=\beta_{0}+\beta_{1} X_{1 i t-2}+\beta_{2} X_{2 i t-2}+\mathbf{e}_{i t-2}$

Keterangan:

Y : Alokasi anggaran (Rp.)

$\mathrm{X}_{1}$ : Informasi finansial (\%)

$\mathrm{X}_{2}$ : Informasi kinerja nonfinansial (ton)

$B_{0}:$ Elemen konstan

$\beta_{1,2}$ : Koefisien regresi

e : Error

i : Satker ke-i (pengidentifikasi cross section), i = $1,2, \ldots, 133$

$\mathrm{t}$ : Periode ke-t (pengidentifikasi time series), $\mathrm{t}=$ $1,2,3,4$

Pengalokasian anggaran tahun $t$ menggunakan informasi finansial dan kinerja nonfinansial tahun t-2 karena dalam siklus APBN proses perencanaan dan penganggaran untuk tahun t dilaku- 
kan pada tahun t-1, sehingga data kinerja tahunan yang tersedia adalah data kinerja tahun t-2. Penaksiran koefisien regresi dari model regresi linier berganda dilakukan dengan metode Ordinary Least Squares (OLS). Penggunaan OLS akan memberikan taksiran koefisien regresi yang bersifat best linear unbiased estimator (BLUE) apabila dapat memenuhi asumsi klasik: nilai tengah error sama dengan nol (zero mean error), tidak terdapat autokorelasi di antara error (Cov $\left.\left(\mathrm{e}_{\mathrm{i}}, \mathrm{e}_{\mathrm{j}}\right)=0, \mathrm{i} \neq \mathrm{j}\right)$, error memenuhi sifat homocedasticity $\left(\operatorname{Var}\left(\mathrm{e}_{\mathrm{i}}\right)=\sigma^{2}\right)$, tidak terdapat kolinieritas di antara variabel bebas, error berasal dari sebaran normal dengan nilai tengah nol dan varian $\sigma^{2}$ ( $\varepsilon \mid x \sim N\left(0, \sigma^{2}\right)$. Analisis data untuk uji asumsi klasik maupun penaksiran koefisien regresi menggunakan bantuan software IBM SPSS Statistics Version 19 .

\section{Kriteria Penerimaan dan Penolakan Hipo- tesis}

Dalam pengujian hipotesis, penelitian ini melakukan Uji F dan Uji t. Uji F digunakan untuk pengujian model dengan kriteria sebagai berikut: $\mathrm{H}_{0}: \mathrm{B}_{1}=\mathrm{B}_{2}=0$

Ha: Minimal terdapat satu B (koefisien regresi) yang tidak sama dengan nol

$\mathrm{H}_{0}$ secara statistik ditolak apabila $p$-Value $\leq \mathrm{a}$, artinya minimal ada satu $B$ yang tidak sama dengan nol. Penolakan $\mathrm{H}_{\mathrm{o}}$ berarti bahwa sebagian keragaman $\mathrm{Y}$ dapat dijelaskan oleh fungsi linier peubah bebasnya, yaitu X.

Uji t digunakan untuk pengujian koefisien regresi yang dalam hal ini adalah pengujian hipotesis penelitian. Pengujian hipotesis pertama memiliki kriteria sebagai berikut:

$\mathrm{H}_{0}: \mathrm{B}_{1}=0$

$\mathrm{H}_{1}: \mathrm{B}_{1}>0$

$\mathrm{H}_{0}$ secara statistik ditolak apabila $p$-Value $\leq \mathrm{a}$, artinya terdapat cukup bukti untuk menyatakan adanya pengaruh positif antara informasi kinerja finansial dengan keputusan alokasi anggaran. Sedangkan pengujian hipotesis kedua menggunakan kriteria:

$\mathrm{H}_{0}: \mathrm{B}_{2}=0$

$\mathrm{H}_{2}: \mathrm{B}_{2}>0$

$\mathrm{H}_{0}$ secara statistik ditolak apabila $p$-Value $\leq \mathrm{a}$, artinya terdapat cukup bukti untuk menyatakan adanya pengaruh positif antara informasi kinerja finansial dengan keputusan alokasi anggaran.

\section{HASIL PENELITIAN DAN PEMBAHASAN}

\section{Statistik Deskriptif}

Variabel informasi finansial berupa tingkat realisasi belanja memiliki wilayah pengamatan dalam rentang 57,93\%-99,92\%, sedangkan varia- bel informasi kinerja nonfinansial berupa volume produksi perikanan budidaya berada dalam rentang 2.939,36 ton - 3.479.419,93 ton. Berdasarkan data penelitian diperoleh nilai rata-rata anggaran dekonsentrasi dan tugas pembantuan yang dialokasikan ke satker dinas kelautan dan perikanan provinsi setiap tahunnya sebesar Rp. 3.641.754.782,00. Alokasi terbesar diberikan ke Dinas Kelautan dan Perikanan Provinsi Jawa Barat tahun 2016 dengan nilai Rp. 9.399.000.000,00, sedangkan alokasi terkecil diberikan ke Dinas Kelautan dan Perikanan Provinsi Bengkulu tahun 2017 dengan nilai Rp. 1.109.253.300,00. Statistik deskriptif variabel penelitian dapat dilihat pada tabel 1 .

\section{Model Penelitian}

Model penelitian yang diestimasi dengan menggunakan OLS menghasilkan persamaan regresi linier berganda sebagai berikut:

\section{Model 1}

$$
\begin{aligned}
Y_{\mathrm{it}}= & 657.846 .647,68+27.951 .542,03 X_{1 \mathrm{it}-} \\
& 2+1.023,30 X_{2 \mathrm{it}-2}+e_{\mathrm{it}-2}
\end{aligned}
$$

Hasil pengujian asumsi klasik menunjukkan bahwa Model 1 hanya memenuhi persyaratan zero mean error dan tidak terdapat kolinieritas, sedangkan persyaratan tidak terdapat autokorelasi, homocedasticity, dan error berasal dari sebaran normal tidak dapat dipenuhi. Penggunaan OLS dalam kondisi terdapat autokorelasi dan/ atau heterocedasticity memang masih menghasilkan taksiran linier yang tidak bias, tetapi akan memiliki nilai varian yang tidak lagi efisien sehingga tidak dapat memenuhi sifat BLUE. Akibatnya, pengujian hipotesis yang dilakukan dapat memberikan kesimpulan yang tidak tepat. Sementara itu, apabila asumsi error berasal dari sebaran normal tidak terpenuhi, maka koefisien regresi juga tidak memiliki sebaran normal. Padahal, pengujian hipotesis yang pada dasarnya menguji koefisien regresi dengan uji $\mathrm{t}$ didasarkan pada asumsi bahwa populasi memiliki sebaran normal. Oleh karena itu, apabila asumsi ini tidak terpenuhi maka hasil pengujian dapat memberikan kesimpulan yang menyesatkan.

Agar asumsi yang dipersyaratkan dalam metode OLS dapat terpenuhi sehingga bisa menghasilkan taksiran yang bersifat BLUE, setiap variabel penelitian ditransformasi ke dalam logaritma natural (Ln), sehingga Model 1 setelah transformasi menjadi model double log sebagai berikut:

\section{Model 2}

$\operatorname{Ln} Y_{\mathrm{it}}=17,680,69 \operatorname{Ln} X_{1 \mathrm{it}-2}+0,10 \operatorname{LnX} 2_{\mathrm{it}-2}+e_{\mathrm{it}-2}$ 
Tabel 1. Statistik Deskriptif Variabel Penelitian

\begin{tabular}{|c|c|c|c|c|}
\hline Variable & Mean & Min & $\operatorname{Max}$ & Standard Deviation \\
\hline Alokasi Anggaran (Y) (Rp.) & 3.641 .754 .782 & 1.109 .253 .300 & 9.399 .000 .000 & 1.691 .201 .371 \\
\hline Informasi Finansial $\left(\mathrm{X}_{1}\right)(\%)$ & 92,18 & 57,93 & 99.92 & 8,55 \\
\hline Informasi Kinerja Nonfinansial ( $\mathrm{X}_{2}$ ) (ton) & $398.024,73$ & $2,939.26$ & $3,479,419.93$ & $615.628,18$ \\
\hline
\end{tabular}

Tabel 2. Hasil Uji Asumsi Klasik

\begin{tabular}{|c|c|c|c|}
\hline Asumsi & Pengujian & Hasil & Kesimpulan \\
\hline Zero mean error & Uji t & $\mathrm{P}$ value $1,00>$ a $5 \%, \mathrm{H}_{0}$ tidak dapat ditolak & $\begin{array}{l}\text { Nilai tengah error sama dengan } \\
\text { nol }\end{array}$ \\
\hline $\operatorname{Cov}\left(e_{i}, e_{j}\right)=0, i \neq j$ & $d$ statistic & d 2,013 berada pada selang $1,747-2,253$ & Tidak ada autokorelasi \\
\hline $\operatorname{Var}\left(\mathrm{e}_{\mathrm{i}}\right)=\sigma^{2}$ & Uji Glejser & $\begin{array}{l}\mathrm{p} \text { value untuk koefisien regresi }>\text { a } 5 \%, \mathrm{H}_{0} \\
\text { tidak dapat ditolak }\end{array}$ & Homocedasticity \\
\hline Tidak ada kolinieritas & VIF & $1,055<10$ & Tidak ada kolinieritas \\
\hline$\varepsilon \mid x \sim N\left(0, \sigma^{2}\right)$ & $\begin{array}{l}\text { Uji Kolmogorov- } \\
\text { Smirnov }\end{array}$ & $\mathrm{P}$ value $0,556>$ a $5 \%, \mathrm{H}_{0}$ tidak dapat ditolak & $\begin{array}{l}\text { Error berasal dari distribusi } \\
\text { normal }\end{array}$ \\
\hline
\end{tabular}

Hasil pengujian asumsi klasik pada Model 2 memberikan petunjuk bahwa Model 2 sudah memenuhi asumsi zero mean error, tidak terdapat kolinieritas, homocedasticity, dan error berasal dari sebaran normal, tetapi dengan nilai Durbin Watson d Statistic 1,512, error pada Model 2 masih bersifat autokorelasi positif. Oleh karena itu, untuk pengujian hipotesis perlu dilakukan transformasi dengan metode generalized difference equation menjadi model sebagai berikut:

\section{Model 3}

$$
\begin{aligned}
\operatorname{Ln} Y_{\mathrm{it}} *=12,61 & +0,93 \operatorname{Ln} X_{1 \mathrm{it}-2} *+0,09 \operatorname{Ln} X_{2 \mathrm{it}-2} * \\
& +e_{\mathrm{it}-2}
\end{aligned}
$$

Dalam model ini:

$\mathrm{LnY}_{\mathrm{it}}{ }^{*}=\mathrm{LnY}_{\text {it }}-0,244\left(\operatorname{Lag} 1 \mathrm{LnY} \mathrm{Y}_{\mathrm{t}-\mathrm{l}}\right)$

$\operatorname{LnX}_{1 i t-2} *=\operatorname{Ln} \mathrm{X}_{1 i t-2}-0,244\left(\operatorname{Lag} 1 \operatorname{LnX} X_{1 i t-2)}\right.$

$\operatorname{LnX}_{2 i-2} *=\operatorname{Ln} \mathrm{X}_{2 i t-2}-0,244\left(\operatorname{Lag} 1 \operatorname{LnX} X_{2 i-2}\right)$

Angka 0,244 merupakan nilai estimasi koefisien autokovarian $(\rho)$ yang didasarkan pada nilai Durbin Watson d Statistic pada Model 2.

Hasil pengujian statistik terhadap asumsi klasik menunjukkan bahwa asumsi klasik yang dipersyaratkan dalam metode OLS untuk Model 3 dapat dipenuhi sebagaimana dirinci dalam tabel 2 . Oleh karena itu, estimasi koefisien regresi pada Model 3 merupakan taksiran linier yang memiliki sifat BLUE, sehingga dapat digunakan untuk menguji hipotesis penelitian dengan kesimpulan yang tidak bias.

\section{Hasil Pengujian Hipotesis}

Pengujian hipotesis dalam penelitian ini terdiri dari dua jenis uji statistik, yaitu uji $\mathrm{F}$ untuk menguji model dan uji t untuk menguji koefisien regresi. Hasil uji $\mathrm{F}$ mendapatkan nilai $\mathrm{p}$ value 0,000. Hal ini menunjukkan penolakan $\mathrm{H}_{0}$ yang artinya bahwa sebagian keragaman alokasi anggaran dapat dijelaskan oleh fungsi linier peubah bebasnya, yaitu informasi finansial dan kinerja nonfinansial. Besarnya bagian yang dapat dijelaskan tersebut diterangkan oleh nilai koefisien determinasi $\left(\mathrm{R}^{2}\right)$ 13,1\%.

Kemampuan informasi finansial dan kinerja nonfinansial dalam menjelaskan keragaman alokasi anggaran mengindikasikan bahwa kedua informasi tersebut merupakan dasar dalam pengalokasian anggaran. Hal ini tampak sebagai salah satu jawaban atas pertanyaan Key (1940) tentang problem utama dalam alokasi anggaran, yaitu ketidakjelasan dasar yang digunakan dalam pengalokasian anggaran. Walaupun pendekatan technical rasional yang berupaya mengintegraskan informasi kinerja dengan keputusan alokasi anggaran seperti ini mulai banyak digunakan, keberadaanya bukan tanpa kelemahan. Pendekatan technical rasional dianggap tidak mampu menjelaskan aspek nonrasional dalam penganggaran (Gibran dan Sekwat 2009). Padahal, pada tingkat birokrasi yang relatif tinggi, keputusan alokasi anggaran tidak bisa dilepaskan dari konteks politik. Bahkan, penganggaran merupakan suatu medan pertempuran politik yang abadi dimana setiap pihak, baik di jajaran eksekutif dan legislatif, berusaha untuk memenangkan kepentingannya masingmasing (Schick 1975).

Uji t digunakan untuk menguji pengaruh informasi finansial dan kinerja nonfinansial terhadap alokasi anggaran dekonsentrasi dan tugas pembantuan. Output hasil analisis regresi dengan SPSS Statistics Version 19 terkait koefisien regresi disajikan dalam tabel 3.

Tabel 3. Hasil Pengujian Regresi

\begin{tabular}{lrrr}
\hline \multicolumn{1}{c}{ Model } & Koefisien & \multicolumn{1}{c}{ t } & Pvalue \\
\hline Konstan & 12,613 & 9,741 & 0,000 \\
Informasi Finansial (\%) & 0,932 & 2,398 & $0,009^{* * *}$ \\
Informasi Kinerja Non- & 0,086 & 3,057 & $0,002^{* * *}$ \\
finansial (ton) & & & \\
\hline
\end{tabular}


Terdapat 2 kesimpulan terkait uji t yang dapat diperoleh dari Tabel 3: pertama, tersedia cukup bukti untuk menyatakan bahwa informasi finansial berpengaruh positif terhadap alokasi anggaran ( $\mathrm{H}_{0}$ ditolak); kedua, tersedia cukup bukti untuk menyatakan bahwa informasi kinerja nonfinansial berpengaruh positif terhadap alokasi anggaran $\left(\mathrm{H}_{0}\right.$ ditolak).

\section{Informasi Finansial Berpengaruh Positif Terhadap Keputusan Alokasi Anggaran Dekonsentrasi dan Tugas Pembantuan}

Sistem akuntansi pemerintahan diharapkan mampu menghasilkan informasi yang berguna, baik untuk keperluan akuntabilitas maupun pengambilan keputusan (decision usefulness). Konsep decision usefulness dapat terwujud apabila principal dan agen melakukan pemindahan sumber daya berdasarkan informasi akuntansi yang tersedia (Ijiri 1983). Dalam pengalokasian anggaran yang merupakan bentuk pemindahan sumber daya, informasi finansial digunakan oleh principal untuk mengevaluasi kinerja agen. Hasil evaluasi ini selanjutnya digunakan sebagai dasar pemberian reward berupa alokasi anggaran yang relatif besar (Reck 2001). Pemberian reward berdasarkan informasi finansial sebagai ukuran kinerja agen merupakan pilihan paling optimal dalam kondisi principal tidak dapat mengamati perilaku agen secara langsung sebagaimana pengelolaan dekonsentrasi dan tugas pembantuan di DJPB.

Penggunaan informasi finansial dalam pembuatan keputusan alokasi anggaran dikonfirmasi oleh hasil penelitian ini. Hasil penelitian memberikan petunjuk tentang adanya pengaruh positif informasi finansial terhadap keputusan alokasi anggaran dekonsentrasi dan tugas pembantuan. Pengetahuan ini konsisten dengan hasil Reck (2001) dan Dorta-Velazques et al. (2010), serta menguatkan indikasi penggunaan informasi finansial dalam pembuatan keputusan alokasi anggaran oleh Daniels dan Daniels (1991), de Sousa et al. (2012), serta Susanto dan Djuminah (2015).

Dalam manajemen pemerintahan, informasi finansial berupa tingkat realisasi belanja merupakan salah satu informasi yang dianggap penting bagi pemerintah. Hal ini ditunjukkan dari banyaknya jenis laporan yang memuat informasi realisasi belanja, yaitu: LRA yang diproduksi melalui SAIBA, E-Monev PP 39 (e-monev.bappenas.go.id), Sistem Monitoring dan Evaluasi Kinerja Terpadu (Smart) Kementerian Keuangan (monev.anggaran. depkeu.go.id), E Dalwas Online Kementerian Kelautan dan Perikanan Republik Indonesia (edalwas.kkp.go.id), Laporan Bulanan Tim Eva- luasi dan Pengawasan Realisasi Anggaran (TEPRA), Laporan Kegiatan Bulanan dan Tahunan, dan Laporan Kinerja Triwulanan dan Tahunan.

Pentingnya informasi realisasi belanja tidak dapat dilepaskan dari pengelolaan makro ekonomi. Pemerintah memiliki keperluan untuk memaksimalkan belanja karena belanja pemerintah yang besar akan memberikan manfaat terhadap pembentukan PDB. Data pertumbuhan ekonomi Indonesia untuk periode 2010-2014 menunjukkan kecenderungan pelambatan ekonomi. Dalam periode yang sama, terlihat kebijakan pemerintah untuk mengendalikan pertumbuhan ekonomi dengan cara menjaga kontribusi belanja pemerintah terhadap pembentukan PDB pada tingkat yang relatif stabil sebagaimana terdapat dalam grafik 1 .

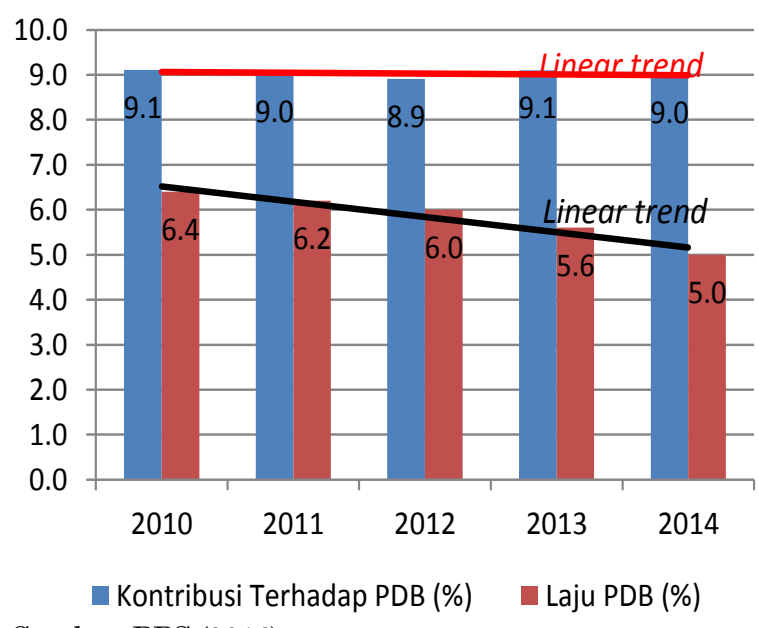

Sumber: BPS (2016)

Grafik 1. Kontribusi Belanja Pemerintah Terhadap PDB dan Laju Pertumbuhan PDB Periode 2010-2014

Ditinjau secara mikro, besarnya realisasi belanja dapat digunakan untuk memaksimalkan utilitas birokrasi satuan kerja pengelolaya. Niskanen (1968) menyatakan bahwa fungsi utilitas birokrasi secara positif berhubungan dengan anggaran sehingga untuk memaksimalkan utilitasnya, birokrasi memiliki perilaku budget maximizer. Dalam hal ini, birokrasi tentu tidak hanya berharap mendapatkan alokasi anggaran yang relatif banyak, tetapi juga berusaha untuk memaksimalkan utilitasnya dengan cara membelanjakan anggaran semaksimal mungkin dari pagu yang ada.

Kecenderungan untuk memaksimalkan realisasi anggaran belanja ini juga terlihat pada satker dekonsentrasi dan tugas pembantuan. Data periode 2012-2014 menunjukkan nilai rata-rata tingkat realisasi anggaran belanja mencapai 92,18\% dengan koefisien variasi yang relatif kecil, yaitu 9,28\%. Kondisi ini mengindikasikan bahwa satker 
dekonsentrasi dan tugas pembantuan memiliki tingkat realisasi anggaran belanja yang tinggi dan relatif homogen antara satker satu dengan yang lain.

Walaupun secara makro dan mikro realisasi belanja berperan penting bagi pemerintah, penggunaannya sebagai informasi finansial dalam pembuatan keputusan alokasi anggaran memerlukan kehati-hatian. Belanja pemerintah hanya akan mampu memperbaiki kinerja, apabila belanja tersebut dilakukan oleh instansi yang sudah menerapkan good governance dengan indikasi rendahnya tingkat korupsi dan tingginya kualitas birokrasi (Rajkumaar dan Swaruup 2007). Oleh karena itu, penggunaan informasi finansial sebagai dasar pemberian reward kepada agen perlu memperhatikan tingkat penerapan agenda reformasi birokrasi di setiap satker dinas kelautan dan perikanan provinsi. Tanpa mengindahkan penerapan good governance melalui reformasi birokrasi, besarnya belanja yang direalisasikan oleh satker bisa jadi tidak dapat menghasilkan perbaikan yang optimal dalam kinerja pemerintah.

\section{Informasi Kinerja Nonfinansial Berpengaruh Positif Terhadap Keputusan Alokasi Anggar- an Dekonsentrasi dan Tugas Pembantuan}

Hasil penelitian ini menunjukkan bukti empiris adanya pengaruh positif informasi kinerja nonfinansial terhadap alokasi anggaran. Hasil ini konsisten dengan Reed (1986) serta Gilmour dan Lewis (2006). Informasi kinerja nonfinansial digunakan untuk menilai kinerja keseluruhan unit kerja dan cenderung dipakai untuk menggantikan ukuran finansial (Reck 2001). Dalam pembuatan keputusan alokasi anggaran, informasi kinerja nonfinansial digunakan sebagai dasar pengalokasian anggaran. Apabila principal puas dengan kinerja nonfinansial agen, maka principal akan memberikan reward berupa alokasi anggaran yang relatif banyak.

Pemberian reward dan sanksi berdasarkan informasi kinerja nonfinansial menjadi bagian dari penerapan akuntabilitas. Akuntabilitas merupakan hubungan antara dua pihak, dimana satu pihak harus akuntabel dengan menyediakan informasi kinerja kepada pihak lain yang memberikan reward atau sanksi berdasarkan informasi kinerja tersebut (Biela dan Papadopoulus 2010). Dalam perkembangannya, akuntabilitas diterapkan di bidang penganggaran dengan bentuk penganggaran berbasis kinerja yang berupaya mengintegrasikan manajemen kinerja dengan manajemen finansial dalam suatu dokumen anggaran.
Di Indonesia, penerapan anggaran berbasis kinerja merupakan bagian dari reformasi perencanaan dan penganggaran yang mulai diterapkan pada permulaan RPJMN 2010-2014. Pemerintah berencana menerapkan anggaran berbasis kinerja secara bertahap. Pada tahap awal, pemerintah mulai melakukan pencantuman informasi kinerja dalam dokumen anggaran tanpa mengkaitkan informasi kinerja tersebut dengan jumlah anggaran yang dialokasikan. Pada tahap akhir penerapan anggaran berbasis kinerja, pemerintah akan mengalokasikan anggaran berdasarkan informasi kinerja. (Direktorat Alokasi Pendanaan Pembangunan 2009)

Apabila dilihat dari alokasi anggaran yang diterima DJPB untuk periode 2010-2017, maka penerapan anggaran berbasis kinerja masih sebagaimana bentuk awalnya, yaitu sekedar pencantuman informasi kinerja dalam dokumen anggaran tanpa menghubungkan alokasi anggaran dengan informasi kinerja yang ada. Padahal, dalam periode 8 tahun tersebut, pemerintah bukan hanya telah menyelesaikan RPJMN 20102014, tetapi juga telah memasuki pertengahan RPJMN 2015-2019. Lambatnya kemajuan reformasi penganggaran ini sejalan dengan Trebby dan van Daniker (1986) yang menyatakan bahwa dalam praktiknya, perubahan pendekatan dalam penganggaran bukan bersifat revolusioner, tetapi lebih cenderung evolusioner dengan proses perubahan yang berjalan sangat lambat.

Hal di atas merupakan indikasi bahwa dalam pembuatan keputusan alokasi anggaran pada tingkat yang relatif tinggi, integrasi informasi kinerja ke dalam keputusan alokasi anggaran relatif sulit dilakukan. Grafik 2 menunjukkan target kinerja dan realisasi outcome volume produksi perikanan budidaya serta alokasi anggaran bagi DJPB. Dalam grafik tersebut terlihat tidak adanya keterkaitan antara informasi kinerja dengan alokasi anggaran, dimana target dan realisasi outcome masing-masing memiliki kecenderungan meningkat mengikuti pola linier sedangkan alokasi anggaran berfluktuasi mengikuti pola polynomial.

Walaupun alokasi anggaran oleh KKP kepada DJPB masih berada pada fase pertama dari tahapan reformasi penganggaran, alokasi anggaran dekonsentrasi dan tugas pembantuan oleh DJPB kepada dinas kelautan dan perikanan provinsi sudah setahap lebih maju karena telah mengkaitkan informasi kinerja nonfinansial dengan alokasi anggaran. Anggaran yang besar diberikan sebagai reward kepada dinas kelautan dan perikanan provinsi dengan kinerja nonfinansial yang relatif baik. Penganggaran berbasis kinerja yang fokus pada informasi kinerja non- 
finansial dalam bentuk outcome semakin banyak diterapkan oleh negara anggota Organization for Economic Cooperation and Development (OECD). Dalam hal ini, outcome harus mampu merefleksikan tujuan dan prioritas pemerintah dan memiliki dampak bagi kehidupan masyarakat. (Diamond 2005)
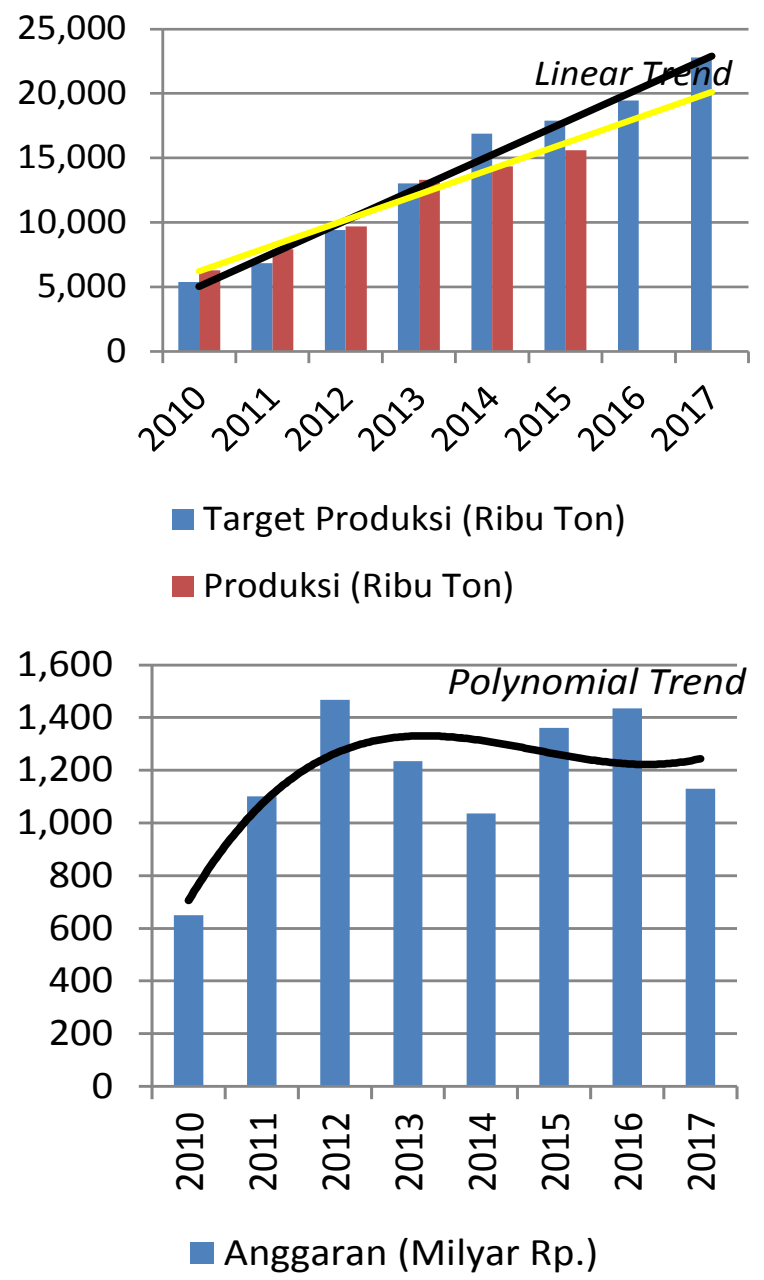

Sumber: DJPB (2015a,b, 2017)

Grafik 2. Target dan Realisasi Produksi Perikanan Budidaya serta Alokasi Anggaran DJPB Tahun 20102017

Apabila ditinjau dari tujuan dan prioritas pemerintah, maka penggunaan outcome volume produksi perikanan budidaya sebagai informasi kinerja nonfinansial memiliki kesesuaian dengan tujuan dan prioritas pemerintah. Dalam RPJMN 2015-2019, pemerintah menetapkan sasaran pokok pembangunan nasional untuk sektor maritim dan kelautan yang salah satu indikatornya adalah produksi hasil perikanan. Sasaran pokok pembangunan ini selanjutnya ditetapkan dalam Keputusan Menteri Kelautan dan Perikanan Nomor 110/ KEPMEN-KP/ 2015 sebagai salah satu indikator Indikator Kinerja Utama dari KKP, yaitu produksi perikanan. Oleh karena itu, outcome volume produksi perikanan budidaya berkontribusi secara langsung terhadap keberhasilan pembangunan kelautan dan perikanan, maupun pembangunan nasional.

Apabila ditinjau dari syarat bahwa outcome yang digunakan harus mengindikasikan dampak bagi masyarakat, maka produksi perikanan memiliki dampak bagi kecukupan penyediaan sumber protein hewani bagi masyarakat. FAO memperkirakan sekitar 1 milyar penduduk dunia bersandar pada ikan sebagai sumber primer protein hewani (FAO 2000 dalam Tidwell dan Allan 2001). Untuk memenuhi kebutuhan ikan tersebut, peran perikanan budidaya semakin besar karena pertumbuhan perikanan budidaya yang relatif cepat dan stok sumber daya ikan laut yang semakin menipis (Tidwell dan Allan 2001).

Dalam kurun 2009-2014, produksi ikan di Indonesia menunjukkan kecenderungan peningkatan. Untuk mencapai produksi ikan ini, perikanan tangkap hanya memberikan kontribusi yang relatif stagnan, sehingga kemampuan suplai ikan di Indonesia semakin bersandar kepada produksi perikanan budidaya. Hal ini disebabkan produksi perikanan budidaya Indonesia tumbuh jauh lebih cepat daripada produksi perikanan tangkap. Grafik 3 menunjukkan volume produksi perikanan Indonesia.

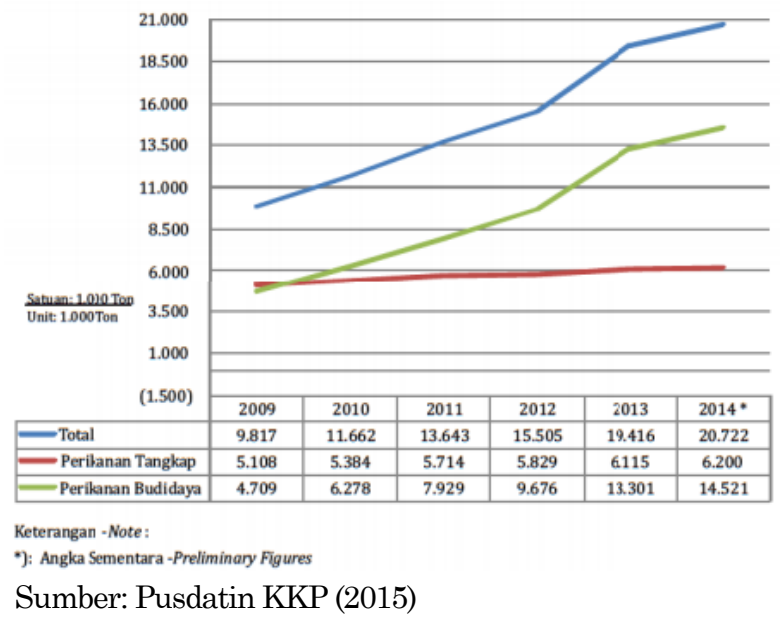

Grafik 3. Volume Produksi Perikanan Indonesia 20092014

Oleh karena informasi kinerja nonfinansial dalam bentuk outcome volume produksi perikanan budidaya ini memiliki peran strategis dalam pembangunan, pemerintah perlu mengenali kelemahan dari informasi kinerja nonfinansial ini sejak awal. Dengan menyadari kelemahan tersebut, ekses negatif penggunaannya dalam evaluasi kinerja dan pengalokasian anggaran dapat dikurangi. 
Penggunaan informasi kinerja nonfinansial sebagai dasar reward dalam situasi kelembagaan yang lemah dapat merangsang agen untuk melaporkan kinerja lebih tinggi dari kondisi sebenarnya. Manipulasi pelaporan kinerja bisa terjadi karena prinsipal tidak memiliki informasi pembanding yang dapat digunakan untuk mengevaluasi informasi kinerja nonfinansial yang dilaporakan agen (van Thiel dan Leeuw 2002). Apabila informasi kinerja nonfinansial tidak menggambarkan kondisi kinerja yang sebenarnya, maka pemberian reward bukan lagi didasarkan pada informasi yang benar sehingga pemberian reward tersebut malah akan menghasilkan perilaku yang kontraproduktif. Untuk mencegah penyajian informasi kinerja nonfinansial yang tidak sesuai realita tersebut, van Thiel dan Leeuw (2002) menyarankan agar principal melakukan investigasi terhadap administrasi dan organisasi yang melaksanakan sistem pengukuran kinerja.

Dalam konteks pengukuran kinerja volume produksi perikanan budidaya, investigasi dapat dilaksanakan untuk menilai kesesuaian sistem statistik perikanan budidaya yang dilakukan provinsi dengan metode survai statistik perikanan budidaya yang dikeluarkan oleh DJPB. Kalau terdapat ketidaksesuaian, maka dinas kelautan dan perikanan provinsi harus bisa menjelaskan bahwa ketidaksesuaian metode survai statistik perikanan budidaya yang dilaksanakannya masih bisa dipertanggungjawabkan secara ilmiah. Tanpa adanya investigasi seperti ini dan dalam kondisi birokrasi yang cenderung budget maximizer, peluang penyajian informasi kinerja nonfinansial yang over estimate menjadi relatif tinggi karena dinas kelautan dan perikanan provinsi berharap bisa mendapatkan reward anggaran yang besar untuk memaksimalkan utilitasnya.

\section{KESIMPULAN DAN SARAN}

\section{Kesimpulan}

Penelitian ini bertujuan untuk memberikan bukti empiris penggunaan informasi finansial dan kinerja nonfinansial dalam pembuatan keputusan alokasi anggaran dekonsentrasi dan tugas pembantuan. Penggunaan informasi tersebut diindikasikan adanya pengaruh positif informasi finansial dan kinerja nonfinansial terhadap alokasi anggaran dekonsentrasi dan tugas pembantuan. Teori utama yang digunakan dalam penelitian ini adalah agency theory. Dalam hubungan keagenan yang ada, DJPB sebagai principal, sedangkan satker dekonsentrasi dan tugas pembantuan sebagai agen. Pengujian empiris terhadap 133 sampel dilakukan dengan regresi linier berganda menggunakan metode OLS. Berdasarkan hasil pengujian empiris, diperoleh kesimpulan:

a. Informasi finansial digunakan dalam pembuatan keputusan alokasi anggaran dekonsentrasi dan tugas pembantuan. Hal ini diindikasikan tersedianya cukup bukti yang menunjukkan bahwa informasi finansial berpengaruh positif terhadap alokasi anggaran dekonsentrasi dan tugas pembantuan. Hasil ini konsisten dengan Reck (2001) dan Dorta-Velazques et al. (2010).

b. Informasi kinerja nonfinansial digunakan dalam pembuatan keputusan alokasi anggaran dekonsentrasi dan tugas pembantuan. Hal ini diindikasikan tersedianya cukup bukti yang menunjukkan bahwa informasi kinerja nonfinansial berpengaruh positif terhadap alokasi anggaran dekonsentrasi dan tugas pembantuan. Hasil ini konsisten dengan Reed (1986) serta Gilmour dan Lewis (2006).

\section{Saran}

Penelitian ini memiliki beberapa keterbatasan. Pertama.Informasi finansial yang digunakan adalah data realisasi anggaran tahun 2012 - 2015. Pada periode tersebut, kecuali tahun anggaran 2015, informasi finansial dalam laporan keuangan masih berbasis kas. Kemungkinan akan memberikan hasil yang berbeda apabila menggunakan informasi finansial dalam laporan keuangan berbasis akrual. Untuk penelitian selanjutnya, Informasi finansial yang digunakan disarankan dapat bersumber dari laporan keuangan berbasis akrual. Informasi finansial yang bersumber dari laporan keuangan berbasis akrual dianggap lebih berguna dalam pembuatan keputusan daripada informasi finansial yang dihasilkan oleh laporan keuangan berbasis kas (Hyndman dan Connolly 2011, de Sousa et al. 2012).

Kedua. Informasi kinerja nonfinansial yang digunakan sebatas outcome. Seiring dengan semakin berkembangnya konsep pengukuran kinerja, penelitian selanjutnya disarankan menggunakan informasi kinerja yang membandingkan cost dengan outcome. Perbandingan seperti ini akan menghasilkan suatu ukuran cost effectivenes yang dikenal sebagai indikator value for money (Diamond 2005).

Ketiga. Penelitian ini sebatas menguji secara empiris penggunaan informasi finansial dan kinerja nonfinansial dalam pengalokasian anggaran dengan mencakup alokasi anggaran pada saat terjadi kenaikan, maupun penurunan total anggaran yang dialokasikan. Agar mendapatkan penjelasan yang relatif lebih lengkap disarankan untuk melakukan pengujian kelangkaan sumber daya yang dicerminkan penurunan total anggaran 
yang dialokasikan sebagai variabel moderating. Hal ini didasarkan pada pendapat Higgins (1984) dalam Reck (2001) yang menyatakan bahwa dalam kondisi terdapat kelangkaan sumber daya, fokus perhatian terhadap kinerja manajemen semakin meningkat.

\section{DAFTAR PUSTAKA}

Aman, Rex T. (2012), Internal User and Uses of Financial Statement Within the Federal Government, Thesis pada Naval Postgraduate School, Monterey, California.

Azis, Harry A. (2015), Peran BPK dalam Mewujudkan Good Governance di Pemerintah Daerah, Makalah Dies Natalis Fakultas Ekonomi dan Bisnis Universitas Brawijaya, Malang, 27 November.

Badan Pemeriksa Keuangan (BPK) (2015), Laporan Hasil Pemeriksaan BPK RI atas Laporan Keuangan Pemerintah Pusat Tahun 2014, Jakarta, BPK.

Badan Pusat Statistik (BPS) (2016), www.bps. go.id.

Baiman, Stanley (1990), Agency Research in Managerial Accounting: A Second Look, Accounting, Organization, and Society, Vol. 15, No. 4, hal. 341-371.

Beaver, William H. dan Joel S. Demski (1974). The Nature of Financial Accounting Objectives: A Summary and Synthesis, Journal of Accounting Research, Vol. 12, hal. 170-187.

Berg, Bruce (Mei 1984), Public Choice, Pluralism, and Scarcity: Implications for Bureaucratic Behaviour, Administration and Society, Vol. 11, No. 1, hal. 71-82.

Biela, Jan dan Yannis Papadopoulus (2010), Strategies for Assessing and Measuring Agency Accountability, Makalah dalam The 32 $2^{\text {nd }}$ EGPA Annual Conference 2010, Toulouse, 7-10 September.

Bird, Richard M. dan Francois Vaillancourt (ed.) (2000), Desentralisasi Fiskal di Negaranegara Berkembang, Jakarta, PT Gramedia Pustaka Utama.

Blondal, Jon R. (2006), Budgeting in Singapore, OECD Journal on Budgeting, Vol. 6, No. 1, hal. 45-85.

Boex, Jamie (2011), Exploring the Measurement and Effectiveness of the Local Public Sector: Toward a Classification of Local Public Sector Finances and a Comparison of Devolved and Deconcentrated Finance, IDG Working Paper No. 2011-05, Urban Institute Center on International Development and Government, Washington D.C, Desember.
Connelly, Michael dan Gary L. Tompkins (1989), Does Performance Matter? A Study of State Budgeting, Policy Studies Review, Vol. 8, No. 2, Winter 1989, hal. 288-299

Daniels, Janet D. dan Craig E. Daniels (1991), Municipal Financial Reports: What User Want, Journal of Accounting and Public Policy, 10, hal. 15-38.

Deegan, Craig (2010), Financial Accounting Theory Edition 3, North Ride NSW, Mc Graw Hill Australia Pty. Ltd.

de Sousa, Rossana G., Adriana F. de Vasconcelos, Roberta L. Caneca, dan Jorge K. Niyama (2012), Accrual Basis Accounting in the Brazilian Public Sector: Empirical Research on the Usefulness of Accounting Information. Makalah dalam $12^{\text {th }}$ USP Congress of Controllership and Accounting, Sao Paolo, Juli.

Diamond, Jack (2005), Establishing a Performance Management Framework for Government, Presupuesto y Gasto Publicio, 40, hal. 159-183.

Direktorat Alokasi Pendanaan Pembangunan (2009), Kerangka Pemikiran Reformasi Perencanaan dan Penganggaran, Jakarta, Bappenas.

DJPB (2015a), Realisasi Anggaran 2015 dan Rencana Kegiatan dan Anggaran 2016 Ditjen Perikanan Budidaya, Materi Finalisasi RKAKL Satker Tugas Pembantuan Lingkup Direktorat Jenderal Perikanan Budidaya, Bandung, 20-24 Oktober.

(2015b), Pedoman Pengukuran Indikator Kinerja Utama Direktorat Jenderal Perikanan Budidaya Tahun 2015-2019, Jakarta, KKP.

Djojohadikusumo, Soemitro (1994), Perkembangan Pemikiran Ekonomi, Dasar Teori Ekonomi Pertumbuhan dan Ekonomi Pembangunan, Jakarta, LP3S.

Dorta-Velazques, Jose A., Javier D. Leon-Ledesma, dan Jorge V. Perez-Rodriguez (Summer 2010), Models of Municipal Budget Allocation: Empirical Data from Spanish Municipalities, Public Budgeting and Finance, hal. 24-46.

Eisenhardt, Kathleen M. (Februari 1985), Control: Organizational and Economic Approaches, Management Science, Vol. 31, No. 2, hal. 134149.

(January 1989), Agency Theory: An Assessment anda Review, The Academy of Management Review, Vol. 14, No. 1, hal. 5774.

Ewell, Peter T. (1999), Linking Performance Measures to Resource Allocation: Unmapped Terraian, Quality in Higher Education, Vol. 5, No. 3, hal. 191-209. 
Feltham, Gerald A. dan Jim Xie (July 1994), Performance Measure Congruity and Diversity in Multiple-Task Principal/Agent Relations, The Accounting Review, vol. 69, No. 3, hal. 429-453.

Forrester, John (2002), "The Principle Agent Model and Budget Theory", dalam A. Khan dan W. B. Hildreth (Ed.), Budget Theory in The Public Sector (hal. 123-138), Westpot-Connecticut, Quorum Book

Gibran, Joan M. dan Alex Sekwat (Winter 2009), "Continuing the Search for A Theory of Public Budgeting", Journal of Public Budgeting, Accounting, and Financial Management, 21 (4), hal. 617-644.

Gilmour, John B. dan David E. Lewis (SeptemberOctober 2006), "Does Performance Budgeting Work? An Examination of the Office of Management and Budget's PART Scores", Public Administration Review, hal. 742-752.

Grizzle, Gloria A. (Spring 1987), "Linking Performance to Funding Decisions: What is the Budgeter's Role?", Public Productivity Review, No. 41, hal. 33-44.

Hyndman, N. dan Ciaran Connolly (2011). "Accruals Accounting in The Public Sector: A Road not Always Taken", Management Accounting Research 22, hal. 36-45

Ijiri, Yuji (1983), "On the Accountability Based Conceptual Framework of Accounting", Journal of Accounting and Public Policy, 2, hal. $75-81$

Ives, Martin (October 1987), "Accountability and Governmental Financial Reporting: Measuring Performance in Governmental Reporting", Journal of Accountancy, Vol. 164, No. 4, hal. 130-134.

Jensen, Michael C. dan William H. Meckling (October 1976), "Theory of the Firm: Managerial Behavior, Agency Cost and Ownership Structure”, Journal of Financial Economic, Vol. 3, No. 4, hal. 305-360.

Jorge, Susana M., Joao B. da Costa Carvalho, dan Maria J. Fernandes, (2008), "From Cash to Accrual in Portuguese Local Government Accounting: What Has Truly Changed", Tekhne, Vol. VI, No. 10, hal. 239-262.

Kementerian Perencanaan Pembangunan Nasional/Badan Perencanaan Pembangunan Nasional (Kementerian PPN/ Bappenas) 2014, "Rencana Pembangunan Jangka Menengah Nasional 2015-2019 Buku I Agenda Pembangunan Nasional", Jakarta, Kementerian PPN / Bappenas.

Keputusan Menteri Kelautan dan Perikanan Republik Indonesia Nomor: 110/ KEPMENKP/ 2015 tentang Indikator Kinerja Utama
Kementerian Kelautan dan Perikanan Tahun 2015-2019

Key, Valdimer O. (December 1940), "The Lack of Budgetary Theory", The American Political Science Review, Vol. 36, No. 6, hal. 1137-1144.

Kivisto, Jussi (2007), "Agency Theory as a Framework for the Government University Relationship", Disertasi pada University of Tampere.

Layzell, Daniel T. (March 1998), "Linking Performance to Funding Outcomes for Public Institutions of Higher Education: The US Experience", European Journal of Education, Vol. 33, No. 1, hal. 103-1011.

Libby, Robert dan Barry R. Lewis (1977), "Human Information Processing Research in Accounting: The State of The Art" Accounting, Organization, and Society, Vol. 2, No. 3, hal. 245-268.

Liguori, Mariannunziata, Mariafrancesca Sicilia, Ileana Steccolini (2012), "Some Like It Nonfinancial: Politicians' and Managers' Views on the Importance of Accounting Information", Public Management Review, Vol. 14, Issue 7, hal. 903-922.

Lindauer, David L. dan Ann D. Velenchik (January 1992), "Government Spending in Developing Countries: Trends, Causes, and Consequences". The World Bank Research Observer, Vol 7, No. 1, hal. 59-78.

Loizides, John dan George Vamvoukas (May 2005), "Government Expenditure and Economic Growth: Evidence From Trivariate Causality Testing", Journal of Applied Economics, Vol. VIII, No. 1, hal. 125-152.

Melkers, Julia dan Katherine Willoughby (MarchApril 2005), "Model of PerformanceMeasurement Use in Local Government: Understanding, Budgeting, Communication, and Lasting Effects", Public Administration Review, Vol. 65, No. 62, hal. 180-190.

Niskanen, William A. May (1968), "The Peculiar Economics of Bureaucracy", The American Economic Review, Vol. 58, No. 2, hal. 293-305.

Nogueira, Sonia Paula S., Susana Margarida F. Jorge, dan Mercedes C. Oliver (2013), "The usefulness of Financial Reporting for Internal Decision Making in Portuguise Municipalities", Management Research: The Journal of Iberoamerican Academy of Management, Vol. 11, No. 2, hal. 178-212.

Peraturan Pemerintah Nomor 71 Tahun 2010 tentang Standar Akuntansi Pemerintahan

Pusat Data, Statistik, dan Informasi (Pusdatin) (2015), " Kelautan dan Perikanan dalam Angka Tahun 2014”, Jakarta, Kementerian Kelautan dan Perikanan. 
Rajkumaar, Andrew S. dan Vinaya Swaroop (2008), Public Spending and Outcomes: Does Governance Matter?, Journal of Development Economics, Vol. 86, hal. 96-111.

Ranis, Gustav (2012), Vertical and Horizontal Decentralitation and Ethnic Diversity in SubSaharan Africa. Working Paper No. 108, Economic Departement Yale University.

Reck, Jackqueline L. (1996), The Usefulness of Financial and Nonfinancial Performance Accountability Information in Resources Allocation Decisions, Disertasi pada University of Missouri-Columbia.

(2001), The Usefulness of Financial and Nonfinancial Performance Information in Resources Allocation Decisions, Journal of Accounting and Public Policy, Vol. 20, hal. 45-71.

Reed, Sarah A. (1984), The Impact of Non-Monetary Performance Measure upon Budgetary Decision Making in the Public Sector, Disertasi pada North Texas State University. (1986), The Impact of Non-Monetary Performance Measure upon Budgetary Decision Making in the Public Sector, Journal of Accounting and Public Policy, Vol. 5, hal. 111140.

Rivenbark, William C. dan Janet M. Kelly (2000), Performance Measurement: A Local Government Response,. Journal of Public Budgeting, Accounting, and Financial Management, 12 (1), Spring 2000, hal. 74-86

Robinson, Marc dan Jim Brumby (2005), Does Performance Budgeting Work? An Analytical Review of the Empirical Literature, IMF Working Paper WP/ 05/ 210.

Scott, William R. (2009), Financial Accounting Theory Fifth Edition, Toronto, Pearson Prentice Hill.

Schick, Allen (1975), The Battle of the Budget, Proceeding of the Academy of Political Science, Vo. 32, No. 1, hal. 51-70.

Shapiro, Susan P. (2005), Agency Theory, Annual Review of Sociology, 31, hal. 263-284.

Sidik, Machfud (2002), Format Hubungan Keuangan Pemerintah Pusat dan Daerah yang Mengacu pada Pencapaian Tujuan Nasional, Makalah dalam Seminar Nasional Public Sector Scorecard, Jakarta 17-18 April.
Stiefel, Leana, Ross Rubenstein, dan Amy E. Schwartz (Fall 1999), Using Adjusted Performance for Evaluating Resource Use, Public Budgeting and Finance, hal. 67-87.

Susanto, Dwi dan Djuminah (2015), The Usefullness of Local Government Financial Statment for Regional Development Planning Process (An Empirical Study Againts the Head of the District Development Planing Agencies in Java and Madura), Procedia Social and Behavioral Sciences, 211, hal. 7580.

Susilo, Wakhid dan Rusdi Akbar (2015), Peran Informasi Akuntansi Sebagai Alat Akuntabilitas Internal, Evaluasi Kinerja Keuangan, dan Pengambilan Keputusan Keuangan pada Instansi Vertikal Pemerintah Pusat. Makalah dalam Simposium Nasional Akuntansi Ke-18 di Universitas Sumatera Utara, Medan, 16-19 September.

Tidwell, James H. dan Geoff L. Allan (2001), Fish as Food: Aquaculture's Contribution, European Molecular Biology Organization Reports, Vol. 21, No. 11, hal. 958-963.

Tollerson, Cynthia D. (2012), The Data Decision Usefulness Theory: An Exploration of Post 1998 Reported Product and Service Segment Data Decision Usefulness, Disertasi pada University of Houston.

Trebby, James P. dan Relmond P. van Daniker (Fall 1986), Relationship of Budgeting and Accounting: Implication for Public Policy, Journal of Applied Business Research, hal. 2332.

Willoughby, Katherine G. (2002), A Multiple Rationality Model of Budgeting: Budget Office Orientation and Analysts' Roles, dalam A. Khan dan W.B. Hildreth (Ed.), Budget Theory in The Public Sector (hal. 104 - 122), WestpotConnecticut, Quorum Book.

van Thiel, Sandra dan Frans L. Leeuw (March 2002), The Performance Paradox in The Public Sector. Public Performance and Management Review, Vol. 25, No. 3, hal. 267-281.

Undang-undang Nomor 23 Tahun 2014 tentang Pemerintahan Daerah. 